\title{
A view on urban regeneration in Turkey with local implications: Bursa case in terms of sustainability
}

\author{
İ. Ö. Eren \& E. Ö. Tökmeci \\ Department of Architecture, Mimar Sinan Fine Arts University, Turkey
}

\begin{abstract}
This paper aims to emphasize the local reflections of urban regeneration which create unique dynamics and interruptions in urban space and life in terms of sustainability. The Doğanbey Project of Mass Housing Development Administration (TOKI) in Bursa is examined in the context of urban sustainability through the process of urban regeneration in Turkey. As an economic and social reality of the 21 st century, global approaches impose their spatial reflections on urban life and space; the city itself is a kind of laboratory of global trends. Urban regeneration is a manner of reaction of the cities with their social, economic, cultural or environmental issues to this transformation process.

Turkey has lived numerous transformation processes within its socioeconomic and cultural milieu throughout history; however the cities did not much change until the appearance of neoliberal strategies in the 1980s. This transformation has been going on with legal urban policies after the year 2000, Ankara - the capital - and Istanbul - the metropolitan city - being the pioneers in this context.

Bursa is one of the most important historical cities of Turkey. It was the first capital of the Ottoman Empire and has always been a strategic city with its unique location, nature and culture. After 1960s, the city has experienced a rapid industrialization process which resulted in an uncontrolled population growth. The city is also a typical case with its urban regeneration process bringing up the critiques focusing on the lack of an integral approach and its social and spatial results which should be the key point for the sustainability of cities with their historical heritages, neighborhoods, local characters, urban morphologies and cultures.

Keywords: urban regeneration, urban morphology, sustainability, Bursa, conservation, urban identity.
\end{abstract}




\section{Introduction}

Turkey, located between Europe and Asia as a cultural and geopolitical bridge, has always owned the characteristics of both cultures throughout its history. This multidimensional interaction has shaped the country's unique structure in terms of economic, social, cultural and spatial issues.

Globalization has different processes and consequences peculiar to every different society, the case is similar with Turkey. One of these processes is urban regeneration, which is the scope of this paper. Turkey experienced numerous transformations in the past, parallel to its dynamics. These experiences caused several urban and social issues like in other industrialized countries. Although the starting point is similar, the result has different consequences. Especially after 1980s, lack of holistic approaches in the planning processes has been seen with the major impact of liberal economy and globalization mechanisms on urban space. Isolated from the linguistic roots of "urban regeneration", most transformation implications caused different interruptions on urban morphology and society such as neighborhood.

On the other hand, some of the environmental, urban and social issues of the cities of the $21^{\text {st }}$ century are being confronted by the philosophy of sustainability. In this context, interruptions mentioned above become vital for cities and cultures that have to be transferred to next generations, on the importance of which this paper is based. Accordingly, the paper aims to focus on the Turkish experiment of urban renewal or regeneration, which usually lacks a social, cultural, economic and spatial integrity in the process of application, in terms of urban sustainability. The specific case of Bursa Doğanbey will be considered as a case study.

Bursa has been one of the most important cities of Turkey with its geographical, cultural and historical background since it was the first capital of the Ottoman Empire. The strategic importance of the city, nourished by its location, geography and fertile land, continued until the conquest of Istanbul in 1453. Although the speed of development in Bursa decreased after this date, the city kept its commercial role for centuries.

The city had an important role on the country's industrialization with its characteristic commercial products during the early years of the Republic (1923). This industrialization process created urbanization consequences such as the growth of population especially after the 1960s. Some new districts were constituted which transformed the morphology and social structure of the city. 1980s were the years of globalization for Turkey, synchronized with the rest of the world, with its spatial and socio-cultural impacts. Different from the previous spontaneous transformations, the 2000s were the predictors of a new period which has a unique character with its strategic legal arrangements done for urban space by the collaboration of municipalities, central governments and the private sector.

Bursa city participated in this process first with The Development Plan for Environmental Organization in Bursa in 1/100000 scale, which aimed to update the urban environment according to contemporary needs. Doğanbey Urban 
Renewal Project has been prepared in this context by the Mass Housing Administration of Turkey (TOKI') and Osmangazi Municipality, in order to renew the district. Although there had been numerous projects for the district, none of them had the ability to rescue it from being a twilight area. So in 2006, the region was announced as an "Urban Renewal Area". The results of this project will be discussed in the paper with its challenges and opportunities in terms of urban sustainability.

\section{Urban sustainability}

Sustainability, as a basic concept of the $21^{\text {st }}$ century, is the long-term maintenance of responsibility, which has environmental, economic, and social dimensions and formulated briefly as "that meets the needs of the present without compromising the ability of future generations to meet their own needs" [1]. Cities, which have the major role on confronting these environmental issues, are attached to urban sustainability with similar themes. There is a wide literature on urban sustainability in which the basic themes are common. For example, European Environment Agency formulates it as "minimizing the consumption of space and natural resources, rationalizing and efficiently managing urban flows, protecting the health of the urban population, ensuring equal access to resources and services, maintaining cultural and social diversity" [2]. After the general outline of this formulation, it is important to clarify the subjects of urban sustainability. According to Wheeler "planning land use and development, urban design, housing, transportation, urban conservation and restoration, energy and material use, green architecture, justice, economic development, population" [3] can be considered as the subjects of urban sustainability. Within the concept of sustainability, sustainable communities are "places where people want to live and work, now and in the future. There is no standard template to fit them all, but they should be:"active, inclusive and safe, well-run, well-connected, well-served, environmentally sensitive, thriving, welldesigned and built, fair for everyone" [4]. It is the human factor which constitutes the base for sustainable communities. The European Declaration of Urban Rights constitutes a bridge between the sustainable city and community which emphasizes the social dimension of the cities. The principles are stated as follows: "transport and mobility, environment and nature in towns, the physical form of cities, the urban architectural heritage, housing, urban security and crime prevention, disadvantaged and disabled persons in towns, sport and leisure, culture, multicultural integration, health, citizen participation, urban management and planning, economic development" [5].

Beside these approaches, it is important to identify the method how the cultural codes should be transferred to the next generations. Thus, all these abstract concepts have to be localized for every city and society. In this paper, it is aimed to consider the urban regeneration in Turkey, in terms of basic common themes of urban sustainability related to urban rights (Table 1). 
Table 1: $\quad$ Basic themes for urban sustainability that will be considered in this paper's scope.

\begin{tabular}{|c|c|}
\hline 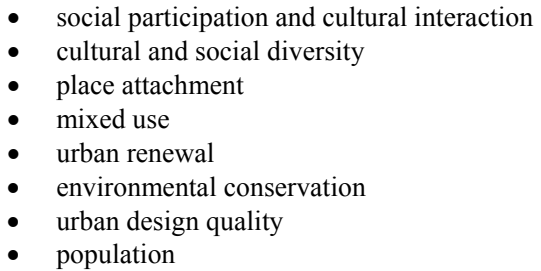 & $\begin{array}{ll}\text { - } & \text { different transportation } \\
\text { - } & \text { easy access to sources } \\
\text { - } & \text { governance } \\
\text { - } & \text { minimising the consumption } \\
\text { - } & \text { health } \\
\text { - } & \text { controlling the development } \\
\text { - } & \text { equality and social justice }\end{array}$ \\
\hline
\end{tabular}

\section{Urban regeneration and Turkey in terms of sustainability}

The roots of urban regeneration, as it is known, are based on the increase of population due to the industrial revolution and the twilight areas born after the $2^{\text {nd }}$ World War. Middleton (1991) states that "the twilight in the city centers are based on poverty, unemployment and the lack of environmental quality" [6]. In addition to these transformations, global trends also affect the urban space. Transportation, commercial and housing areas or social services and their accessibilities in the city, change the density of building dispersions. These facts inevitably give way to urban regenerations. In order to regain these problematic areas to urban life, regeneration projects have to have the "holistic approach between physical, social, spatial substructures of urban life and actors of the sector" [7] which indicates the success of projects.

The process that causes issues on urban space is similar to Europe, although the social, political and economic characteristics of Turkey create unique consequences. In the early years of the Republic (1923), new strategies were developed on infrastructure investment and public works, so there had not been great transformations on urban space till 1950s after when we witness greater social and spatial transformations in terms of technology, politics and socioeconomy. Due to the rapid growth of the country, disintegrated approaches in urban planning strategies caused spontaneous urban areas such as slums or uncontrolled industrial regions. The strategy, based on railway network, was changed to the advantage of highway network in those years and this created a new urban morphology; we see all around the country that the traditional city borders were dissolved in order to set up a new city just near the walls of the old one. New building typologies were added to the city; apartments, slums or mass buildings. But the traditional building culture did not much change till 1980s. Ataöv and Osmay [8] mention about three basic periods regarding urban transformations since 1950s: the years between 1950-1980 in which economic growth and industrialization have a major effect on urban life; the years between 1980 and 2000 in which the cities were affected by neo-liberal politics; the period since 2000s in which regeneration is defined as a strategy with the collaboration of local municipalities and private sector [8]. As Türkün states, "the growing power of the urban coalition has become dominant in Turkey after the 2000s. It is observed that the actors of the central and local governments as 
well as the authorities of important state institutions have become part of this coalition with the same hegemonic neo-liberal discourse especially related to urban transformation driven by the motive of increasing urban land rents and real-estate development. This discourse and the accompanying implementations have also been strongly supported by the private-sector actors, such as developers, land owners, advisors, professionals, and the leading media. The power of this coalition has been enhanced by means of changes made in current laws and enactment of new laws as well as the increasing initiative of particular state institutions, such as the Mass Housing Development Administration (TOKI) and Privatization Administration" [9].

\section{Bursa case}

Bursa is located in the northwestern part of Turkey, in the Marmara Region. Settled on a sloping land between the mount Uludag $(2543 \mathrm{~m})$ and the Bursa plain, the city is developed in the east-west direction. It has been one of the most important cities of Turkey with its geographical, cultural and historical background for centuries. Today it is the fourth most-developed city in the country.

\subsection{Bursa urban history and identity}

The first settlements in the region around Bursa date back to $2000 \mathrm{BC}$, to the times of the Bityhnia Kingdom after which the whole region was known by the name Bithynia. The initial city was founded by King Prusias in the $3^{\text {rd }}$ Century BC. In 74 BC Bursa was captured by the Roman Empire and was included in Byzantine territory after 395 AD. Under the reign of the Roman and Byzantine Empires, the city consisted of a palace, marketplace, churches and around 2000 houses which were constructed inside a fortress. Known to be economically active, the city was also famous for its thermal baths.

In the years following the establishment of the Ottoman Empire, Bursa was besieged by Osman Gazi and conquered in 1326 by his son Orhan Gazi who declared it as the capital city of the Empire. The city witnessed to the construction of the first Ottoman city which developed outside the fortress by the building complexes of Orhan Gazi and the preceding Sultans. The Big Mosque, several khans and a large marketplace consisting of both open and covered spaces laid the ground for the physical and functional formation of the Ottoman city center. Within the mid- $15^{\text {th }}$ century, Bursa had become the biggest and most famous trade center in the Ottoman Empire, specializing mostly on the production and trade of silk as well as various textiles. In the $15^{\text {th }}$ century, the city was the center of Ottoman science and Anatolian mysticism at the same time.

After the conquest of Istanbul by the Ottomans in 1453, the city lost part of its significance against Istanbul's increasing power; however, it maintained its fame both as a trade center and a thermal resort for centuries. Having completed its major urban development until the end of the $15^{\text {th }}$ century, the physical appearance of Bursa stood stable throughout the pre-industrialization period with 
its traditional settlements that were formed in the order of neighborhoods in the Ottoman context. These neighborhoods were grouped around small mosques or dervish lodges which, in most cases, also determined the name of the neighborhood while in some cases neighborhoods were named after the main occupations or ethnic identities of their residents. Bursa had the image of an open city with the large gardens and vineyards between its neighborhoods as well as the fertile Bursa plain which led to its recognition as "Green" Bursa until the mid- $20^{\text {th }}$ century.

In the $19^{\text {th }}$ century, the Ottoman Empire started to turn its direction into industrialization with the declaration of the Tanzimat Charter in 1839. Bursa had its share of this process under the efforts of the government to reconstruct the city in a modernist context especially after $1855 \mathrm{~s}$. The first cadastral map of the city was prepared in 1862 and in the following sixty years new roads were constructed. Moreover, the first silk factory of the Empire was established in Bursa which was followed by the founding of the press in 1888 .

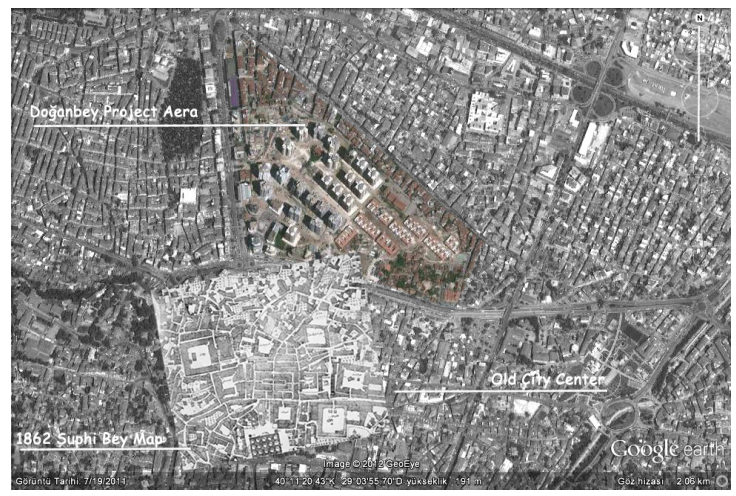

Figure 1: Multilayered layout of the old city center and its closed neighborhoods with Doğanbey, Kiremitçi, Tayakadın and Kırcaali. The traces of the transformation processes of the city can be followed from the differences between the old and new maps. Photo: Prepared from Suphi Bey Map (1862) and Google earth view (2011).

After the $1^{\text {st }}$ World War, the Turkish Republic was established in 1923. Parallel to the new government's policies, the French urban planner Henry Prost prepared a development plan for the city in 1940, which focused on opening new areas of settlement forming the basis of later plans. In 1960, Luigi Piccinato was the advisor for the urban development plan of Bursa, suggesting a linear development for the city in the east-west direction and the establishment of an industrial area. Following this plan and parallel to the country's policy of industrialization, the first organized industrial area in Turkey was established in Bursa in the early 1960s, resulting in an uncontrolled population growth. After 1970 s, the process of industrialization gained greater acceleration leading to 
major transformations in the morphological and socio-cultural structure of the city with an unplanned urbanization.

In parallel to the efforts to preserve the Bursa Plain and the urban character of the city, Bursa Historical, Natural and Archaeological Conservation Areas were defined in 1978, followed by the declaration of the terms of restructuring in these areas. In the $1980 \mathrm{~s}$, development plans concerning several conservation areas of the city were prepared according to these terms. The urban development plan of 1984 introduced new enlargement areas for the city in order to meet up the needs of the growing population. However, these precautions could not prevent the unplanned growth of the city which can be traced from its macro-form.

\subsection{Urban regeneration in bursa}

After the 1980s, liberal economy in Turkey reflected itself into the practice of spatial production where new strategies were determined according to sociocultural and economic factors. However, spatial transformations in cities took place naturally in their own social and economic dynamics until 2000s. After this date, urban regeneration was defined as a strategy with the collaboration of the local authorities and the private sector. The Development Plan for Environmental Organization in Bursa in 1/100000 scale which started in 1998, put on the agenda the revisions of the areas which could not fulfill the actual needs of the city encouraging urban regeneration or renovation projects in various regions of the city by either competitions or public enterprises. The ongoing urban regeneration projects in Bursa today are as follows: (Table 2).

Table 2: Regeneration projects in Bursa. Source: Urban Regeneration and Bursa report, 2008.

\begin{tabular}{|l|l|}
\hline $\begin{array}{l}\text { Bursa Kükürtlü Dericiler Urban Regeneration and Development Project, Bursa } \\
\text { Santral Garajve Yakın Çevresi Urban Regeneration and Development Project, } \\
\text { Emirsultan Camive Yakın Çevresi Urban Regeneration and Development } \\
\text { Project, Yalova Yolu Urban Regeneration and Development Project }\end{array}$ & $\begin{array}{l}\text { Bursa } \\
\text { Metropolitan } \\
\text { Municipality }\end{array}$ \\
\hline $\begin{array}{l}\text { Bursa Yıldırım Sinandede Mahallesi Urban Regeneration Project, Bursa } \\
\text { Yıldırım Beyazıt Mahallesi Urban Regeneration Project, Bursa Yıldırım } \\
\text { Yiğitler Social Housing Project, Bursa Yıldırım Akçağlayan Bahçeli Evleri } \\
\text { Social Housing Project }\end{array}$ & $\begin{array}{l}\text { Yıldırım } \\
\text { Municipality }\end{array}$ \\
\hline Bursa Osmangazi Doğanbey Urban Renewal Project & $\begin{array}{l}\text { Osmangazi } \\
\text { Municipality }\end{array}$ \\
\hline Bursa Karacabey Hamidiye Mahallesi Urban Regeneration Project & $\begin{array}{l}\text { Karacabey } \\
\text { Municipality }\end{array}$ \\
\hline
\end{tabular}

\subsection{The Doğanbey Urban Renewal Project}

The area of the Doğanbey Urban Renewal Project is in the city center of Bursa within the territory of the district of Osmangazi. The $282000 \mathrm{~m}^{2}$ project area is located between three main streets, on the land of four ancient neighborhoods which are Doğanbey, Kiremitçi, Tayakadın and Kırcaali. The project concept was based on the arguments of nonfunctional - noneconomic and unsuitable 
infrastructure of the region. The settlement here consisted of 1-2 story freestanding houses mostly with gardens which offered poor living conditions to their lower-income residents who could not afford to rehabilitate them.

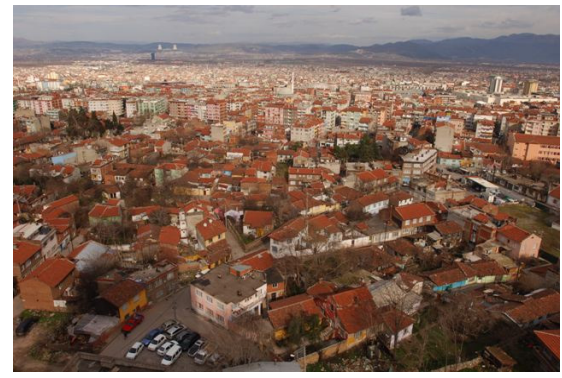

Figure 2: General view of Doğanbey district before the renewal project. Photo: http://www.kents eldonusum.info (Access date: April 2012).

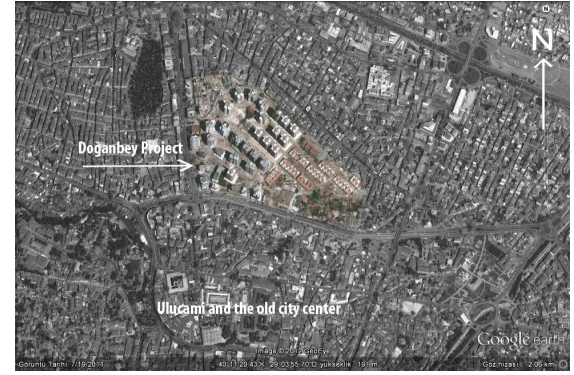

Figure 3: Map of Doğanbey project area and the old city center. The difference of the new project is legible with its morphology. Photo: regenerated from Google Earth, 2012.

The project area was formerly declared as a "Central Business District" in 1993 because of its central location which is very close to the historical commercial center of the city. However, the social and economic structure of the area was not suitable for undertaking the renovation process. The result was a ribbon development on the surrounding few parcels while the Doğanbey neighborhoods remained as they were. In the year 2005, The Osmangazi Municipality approved the revision for the Central Urban Development Project which warranted the building of four stories in an attached order in the parcels which are subject to urban regeneration. Finally, in 2006, the Bursa Metropolitan Municipality, the Bursa Osmangazi Municipality and the Mass Housing Development Administration (TOKI) agreed on the Bursa Osmangazi Doğanbey Urban Renovation Project which would enable to build 2500 luxury houses and $50000 \mathrm{~m} 2$ of open space on the $282000 \mathrm{~m} 2$ area of Doğanbey neighborhoods. The process of regeneration in the Doğanbey neighborhoods started in 2007 after coming to an agreement with the residents. Contracts were signed with the rightholders of around 4300 people, with the commitment of delivery in 18 months. The site was cleared of the former buildings and reconstruction started in stages $[10,11]$.

However, the initially made commitments were not accomplished by the authorities; major changes were made in the proposed project concerning the height of the buildings which in final reached 23 stories, the new houses were not delivered on time and the right-holders were asked to pay high compensations. This led to the organization of the right-holders against the 
process and the start of a legal struggle between the parts. Moreover, the Bursa Agency of the Chamber of Architects organized a photography competition under the name "The slap of TOKI to Bursa" with the critique that TOKI ignored the social, cultural and geographical characteristics of the city by the application of monotype buildings which did not harmonize with the present urban texture [12].

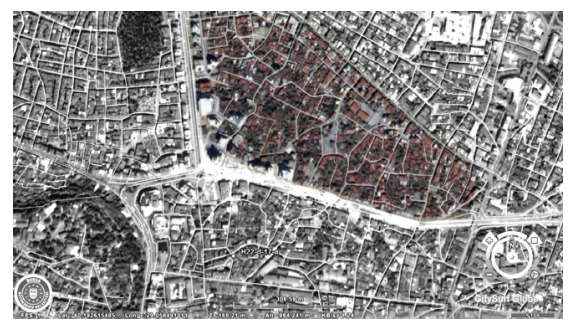

Figure 4:
Air view of Doğanbey, 2002 before the clearance. Photo: Bursa Municipality Geographical Information System.

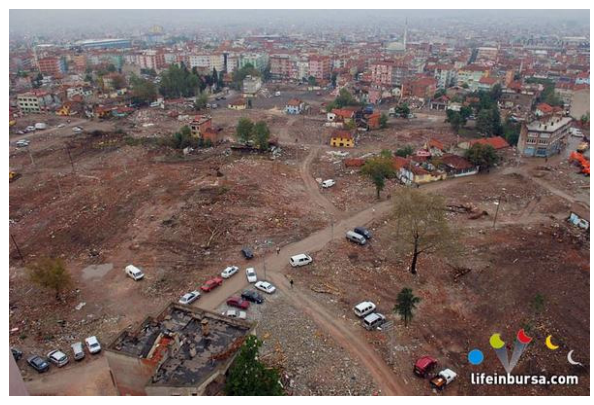

Figure 6: Project area after the "site clearance". Photo: http://www.lifeinbursa. com (Access date: April 2012).

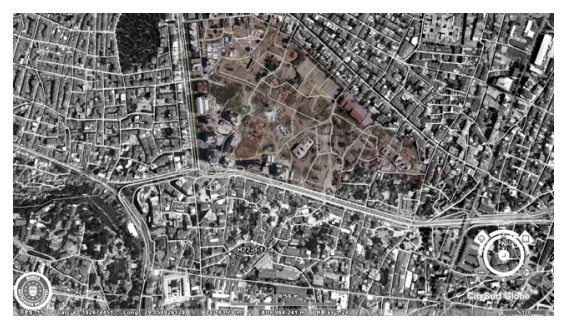

Figure 5:

Air view of Doğanbey, 2009 just after the clearance. Photo: Bursa Municipality Geographical Information System.

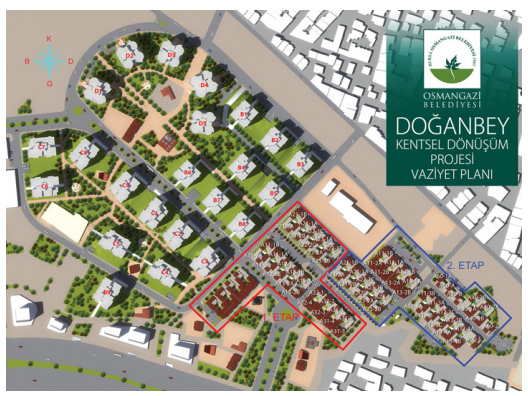

Figure 7:

General layout of the project. Photo: Urban Regeneration and Bursa report, 2008.

\subsection{The evaluation of the Doğanbey project}

The significance of the Doğanbey project lies in its being an intensive application of urban regeneration developed in a historical city center and the pioneer in Bursa. The project area is one of the earliest neighborhoods of the city which is very close to the historical center. Although the area itself is not defined 


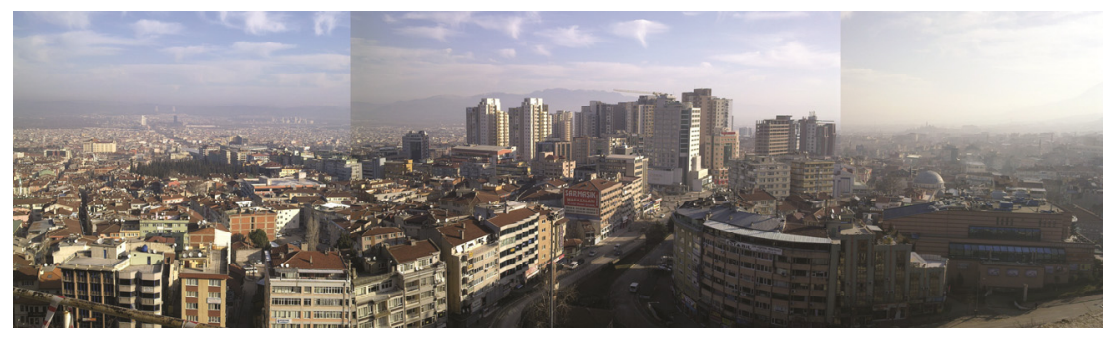

Figure 8: A view from the Bursa Clock Tower to Doğanbey District., Photo: İ. Eren, February 2012.

as a historical site, its closeness to the site area makes it a unique place which should have been evaluated in its own terms before making any long-term alterations. It was meaningful with its neighborhood, street-building typology, place-attachment or morphological factors. However, the current project seems to have ignored the specialties of the area and concentrated on the building of skyscrapers which contrast the present urban fabric, in order to obtain economic benefit. This style of monotype construction threatens the city silhouette visually as well as bringing new physical and spatial problems to the area. The new project increased the density of population from "75-100 people/ha into 800 people/ha" [14], which will obviously cause transportation, traffic and pollution problems either in the area or in the city center.

An urban regeneration project should initially concentrate on the rehabilitation of the proposed area by trying to dismiss the reasons of urban collapse with a multi-disciplinal approach. In the regeneration project of the Doğanbey neighborhoods, however, the initial point was site-cleaning instead of rehabilitation where the main approach was destructing the present and constructing the new. Moreover, the project dislocates most of the former residents of the Doğanbey neighborhoods due to economical and socio-cultural factors. This kind of approach obviously does not correspond to the general philosophy of urban regeneration which should aim at a long-term solution focusing on the needs of the original residents of the area, thus, urban sustainability.

The project causes an interruption in urban sustainability because it ignores main features of the concept; it does not encourage social participation and cultural interaction among its parts; neither does it support cultural and social diversity among the members of the society. The living styles, preferences and expectations of the former residents are reduced to a monotype housing which is far from being economically efficient in the long-run. The project ignores environmental conservation and deforms the city silhouette with its huge mass which overwhelms the existing urban fabric. The urban characteristics of Bursa such as the morphology and the historical neighborhood structure -which is the base of social life in traditional Turkish cities-, are broken, which also splits the collective memory instead of transferring it into future generations. The partially-managed character of the projects disable its integration the city as well as its contribution to historical continuity. 
Beside these criticisms, the main argument of the owners of the project is, they provide new and comfortable houses for the right-holders instead of their old, cheap and un-qualified houses. Also they defend the project with its new face that fits the 21 st century urban image, instead of a twilight housing area.

In sum, the Doğanbey project adds to the on-going debates on urban regeneration in terms of sustainability by showing the multidimensional mistakes which should be avoided in future applications.

\section{Conclusion}

Cities, as living organisms, inevitably are faced with transformations due to time and its dynamics. The basic issue here must be to define the method of transferring the cultural codes into the future.

The urban regeneration applications in Turkey have various problems caused by the lack of an agreement among legal policies, community, local administrations and academic background. This fragmental structure which lacks an integral approach results in an unsustainable and unmanageable character concerning the transformation processes just like the one we witness in the Doğanbey case. Beside this fact, the flue character of transformations named as "renewal", "regeneration" or "conservation" makes an addition to this milieu; for example we witness that "registered sites can be separated from the urban conservation committees in order to renew and can be given to renewal committees" [15]. It is necessary to "re-conceptualize the traditional urban conservation planning as a component of sustainable urban regeneration" [16]. It is clear that the process of urban regeneration which mostly results in unpredictable consequences must be handled through a strategic plan that should be held by the participation of all actors. Either simultaneous or diachronic, only the approaches through integral plans can provide us to transfer the unique characters of our cities and societies into the future.

As international agreements and approaches emphasize the value of local implications, detailed methods in the country-scale should be organized step by step and developed in a strategic plan on how to translate this conceptual framework into concrete projects. Thus, integrity and harmony in cooperation may provide the cities and societies to sustain their cultural, spatial and historical potentials which are occasional for the world heritage in terms of sustainability.

\section{References}

[1] United Nations World Commission on Environment and Development (WCED), 1987.Our Common Future. http://www.un-documents.net/ocf02.htm (Access date: April 2012).

[2] European Environment Agency, 1995, cited in Lautso, K. and Spiekermann, K. and Wegener, M., Modeling Policies for Urban Sustainability, paper presented at 42nd Congress of the European Regional Science Association, Dortmund, 27-31 August 2002. http://www.spiekermann-wegener.com (Access date: April 2012). 
[3] Wheeler 2004:66-84 cited in Bayındırlık Bakanlığ1 Kentleşme Tematik Grubu 2.Raporu: Kentleşme Alanında Sürdürülebilirlik Çözümlemesi: Yaklaşımlar, Modeller, Temel Alanlar, Göstergeler, Uygulama Örnekleri, 2002. http://www.bayindirlik.gov.tr (Access date: March 2012).

[4] Bristol Accord, 2005. http://www.mo.org.tr/UIKDocs/bristolaccord.pdf, (Access Date: October 2011).

[5] The European Urban Charter, 1992. http://sustainablecities.eu/upload/pdf_files/URBAN_CHARTER_EN.pdf. (Access date: April 2012).

[6] Middleton, 1991 cited in Uyan, A., Kent Merkezlerindeki Konut Alanlarında Çöküntüleşme v eDönüşüm "Bursa Doğanbey Kentsel Dönüşüm Projesi Örneği”, Gazi Üniversitesi, Fen Bilimleri Enstitüsü, Basılmamış Yüksek Lisans Tezi, Ankara, 2008, pp. 6.

[7] Ibid, pp. 6.

[8] Ataöv, A., and Osmay, S. Türkiye'de Kentsel Dönüşüme Yöntemsel Bir Yaklaşım, ODTU Mimarlık Fakültesi Dergisi: Ankara, vol.24, 2007, pp. 57-82.

[9] Türkün, A. Urban Regeneration and Hegemonic Power Relationships, International Planning Studies, Vol. 16, No. 1, February 2011, pp. 61-72.

[10] Uyan, A., Kent Merkezlerindeki Konut Alanlarında Çöküntüleşmeve Dönüşüm "Bursa Doğanbey Kentsel Dönüşüm Projesi Örneği”, Gazi Üniversitesi, Fen Bilimleri Enstitüsü, Basılmamış Yüksek Lisans Tezi, Ankara, 2008, pp. 155.

[11] Urban Regeneration and Bursa Report, 2008.Union of Chambers of Turkish Engineers and Architects (UCTEA) Chamber of City Planners Bursa Agency. Reference: http://archweb.metu.edu.tr/arch505/img/bursacity.pdf. (Access date: 13 April 2012).

[12] Ekinci, O., Kente Saygisızlık Belgelendi, CumhuriyetGazetesi, 1 December 2011. (Available at: http://www.cumhuriyet.com, access date 13.04.2012).

[13] Deniz, R. Müsteşardan Doğanbey İtirafi, Bursa Haber Ajansl, 17/02/2012, http://www.bursahakimiyet.com.tr (Access date: April 2012).

[14] Bursa'da TOKI Konutları, 2012. http://www.bursamimar.org.tr (Access date: 04.2012).

[15] Ahunbay, Z., Koruma Kurullarından Koparılan Yenileme Alanları, Mimarist, January 2011. (Available at http://www.planlama.org, Access date: September 2012).

[16] Kocabaş, A. Urban Conservation in Istanbul: Evaluation and ReConceptualization, Habitat International, no.30, 2006, pp. 107-126. doi:10.1016/j.habitatint.2004.08.001. 